\title{
Synthetic Chemically Modified mRNA (modRNA): Toward a New Technology Platform for Cardiovascular Biology and Medicine
}

\author{
Kenneth R. Chien ${ }^{1,2}$, Lior Zangi ${ }^{3}$, and Kathy O. Lui ${ }^{1}$ \\ ${ }^{1}$ Department of Stem Cell and Regenerative Biology, Harvard University, Cambridge, Massachusetts 02138 \\ ${ }^{2}$ Department of Cell and Molecular Biology and Medicine, Karolinska Institutet, Stockholm 171 77, Sweden \\ ${ }^{3}$ Department of Cardiology, Children's Hospital Boston, Boston, Massachusetts 02115 \\ Correspondence: kenneth.chien@ki.se
}

Over the past two decades, a host of new molecular pathways have been uncovered that guide mammalian heart development and disease. The ability to genetically manipulate these pathways in vivo have largely been dependent on the generation of genetically engineered mouse model systems or the transfer of exogenous genes in a variety of DNA vectors (plasmid, adenoviral, adeno-associated viruses, antisense oligonucleotides, etc.). Recently, a new approach to manipulate the gene program of the adult mammalian heart has been reported that will quickly allow the high-efficiency expression of virtually any protein in the intact heart of mouse, rat, porcine, nonhuman primate, and human heart cells via the generation of chemically modified mRNA (modRNA). The technology platform has important implications for delineating the specific paracrine cues that drive human cardiogenesis, and the pathways that might trigger heart regeneration via the rapid generation of modRNA libraries of paracrine factors for direct in vivo administration. In addition, the strategy can be extended to a variety of other cardiovascular tissues and solid organs across multiple species, and recent improvements in the core technology have supported moving toward the first human studies of modRNA in the next 2 years. These recent advances are reviewed along with projections of the potential impact of the technology for a host of other biomedical problems in the cardiovascular system.

$\mathrm{O}$ ver the past decade, a host of new disease targets and pathways have been uncovered via advances in human cardiovascular genetics and genetically engineered murine model systems. At the same time, new strategies for heart regeneration have been developed in parallel, in both cell-based therapy (Bolli et al. 2011; Makkar et al. 2012; Malliaras et al. 2014) as well as paracrine protein factor therapy (Hendel et al. 2000; Sato et al. 2001; Henry et al. 2003), which are designed to expand and differentiate rare subsets of endogenous heart progenitors in the setting of the injured and failing heart (for review, see Hinkel et al. 2011; Sanganalmath and Bolli 2013). To capitalize on these molecular advances, a variety of technology platforms to

Editors: Margaret Buckingham, Christine L. Mummery, and Kenneth R. Chien

Additional Perspectives on The Biology of Heart Disease available at www.perspectivesinmedicine.org

Copyright (C) 2015 Cold Spring Harbor Laboratory Press; all rights reserved; doi: 10.1101/cshperspect.a014035

Cite this article as Cold Spring Harb Perspect Med 2015;5:a014035 
K.R. Chien et al.

affect the program of gene expression within the heart have been used in experimental models and/or clinical settings, including neutralizing antibodies (Purdham et al. 2008; Kobara et al. 2010), recombinant protein therapeutics (Hendel et al. 2000; Sato et al. 2001; Henry et al. 2003; Gao et al. 2011; Wu et al. 2011; Lin et al. 2012), microRNAs and antagomirs (van Rooij et al. 2008; Eulalio et al. 2012; Chen et al. 2013a; Hinkel et al. 2013), antisense oligonucleotides (Hagiwara et al. 2011), RNAi (Majmudar et al. 2013; Wu et al. 2014), and gene therapy via plasmid (Losordo et al. 1998; Stewart et al. 2009) and viral (Hedman et al. 2003; Stewart et al. 2006) vectors (Fig. 1). The development of new technology platforms to rapidly, transiently, and quantitatively express proteins exclusively in heart in vivo after injury in small and large animals, as well as in the clinically setting, could potentially enhance our capacity to quickly translate new

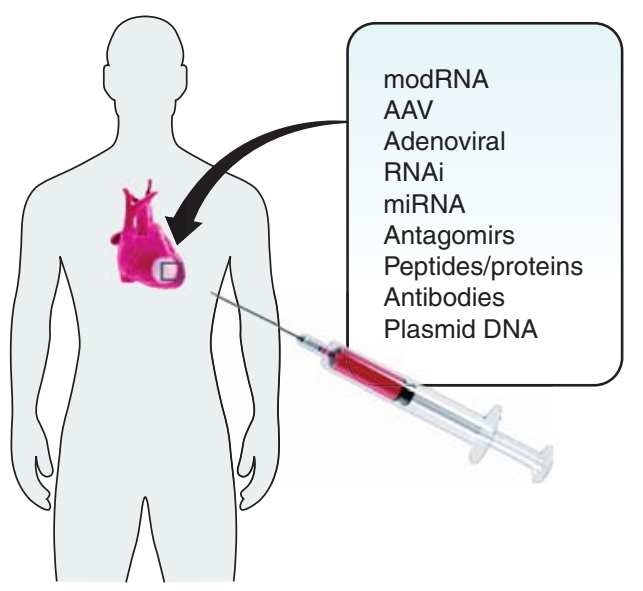

Figure 1. Approaches to manipulate the molecular pathways of the human heart in vivo. A host of independent approaches have been developed to target specific pathways in the heart in vivo in both experimental animals and the clinical setting. These range from DNA-based gene therapy vectors, oligonucleotides, peptides and recombinant proteins, and antibodies. More recently, RNA-based vectors have been developed, including microRNA and their antagonists and RNA interference agents. Chemically modified mRNA (modRNA) joins this list and has distinct advantages for the rapid, in vivo, high-efficiency expression of virtually any protein in the intact heart in a newly developed protocol. findings in traditional genetic-based models systems toward clinical application.

Toward this goal, synthetic, chemically modified mRNA has emerged as a new approach to express proteins in in vitro (Warren et al. 2010; Lui et al. 2013a) as well as in vivo (Kormann et al. 2011; Lui et al. 2013a; Zangi et al. 2013) model systems. Recent studies have extended the initial observations to the heart (Zangi et al. 2013), lung (Kormann et al. 2011), and skeletal muscle (Kormann et al. 2011; Zangi et al. 2013) in vivo, with a particular focus on its potential use in regenerative cardiology to identify paracrine factors that can drive progenitor cell fate decisions, as well as transiently express paracrine factors that can drive the expansion of heart progenitors in vivo and augment cardiovascular regeneration following myocardial infarction (Zangi et al. 2013). This review will highlight these recent advances, including a detailed experimental protocol for implementation, a discussion of the challenges, and opportunities to move the technology forward both as an experimental tool and a potential therapeutic agent. Finally, a discussion of the hurdles to unlock the long-term potential of the platform for cardiovascular biology and medicine in general, and regenerative cardiology in particular, will be presented.

\section{SYNTHETIC, CHEMICALLY MODIFIED mRNA AS A TOOL FOR PROTEIN EXPRESSION}

Early studies by Kariko and Weissman first used chemically modified mRNA as a tool to express proteins of interest in target cells in vitro (Kariko et al. 2005, 2011). Any unmodified mRNAs, including mRNA, that enter the cells via the cell membrane are recognized by the innate immunity (Weissman et al. 2000; Ni et al. 2002; Kariko et al. 2004). Toll-like receptors 7 and 8 are a part of the innate immune system and can recognition ss-mRNA in the endosome (Kariko et al. 2005). Activation of the Toll-like receptor pathway ultimately shuts down host cell protein synthesis, the release of interferons and cytokines, and leads to cell death, a problem that has traditionally prevented their use as a tool for gain- 
New Technology Platform for Cardiovascular Biology

of-function studies (Fig. 2) (Kariko et al. 2005). However, by modifying the nucleotides in the in vitro transcription system, initially substituting pseudouridine for uridine and 5-methyl-cytosine for cytosine (Kariko et al. 2005, 2011), it was found that change in one or two modified nucleotides leads to a change in the secondary structure of the mRNA that allow modified mRNA to escape detection by the innate immunity response of the host cell, and still allow the translational machinery to efficiently express a given protein of interest in living cells in vitro (Kariko et al. 2005, 2011). This approach primarily has been used in in vitro transfection model systems, including reprogramming strategies to express the four reprogramming proteins, resulting in efficient generation of induced pluripotent stem (iPS) cells from a variety of somatic cell types (Warren et al. 2010). In addition, a few studies showed that the approach might allow the short-term in vivo expression of proteins in various disease model systems
(Kormann et al. 2011; Kariko et al. 2012; Zangi et al. 2013), but the requirement for repeated, long-term, high-level expression in certain settings of protein replacement therapy blunted its potential utility in this setting.

\section{IN VITRO AND IN VIVO TRANSFECTION OF CARDIAC AND SKELETAL MUSCLE CELLS}

Previous studies have documented that naked plasmid DNA can be taken up by both cardiac (Losordo et al. 1998; Stewart et al. 2009; Zangi et al. 2013) and skeletal muscle (Braun 2004; Taniyama et al. 2012), which leads to a very localized level of expression in vivo, a feature that is unique to muscle tissue. These earlier studies suggested the possibility that muscle might also have a unique, higher level of capability of taking up modified mRNA that might result in a higher efficiency of expression than has been reported in other tissues. As recently described, both cardiac (Zangi et al. 2013) and

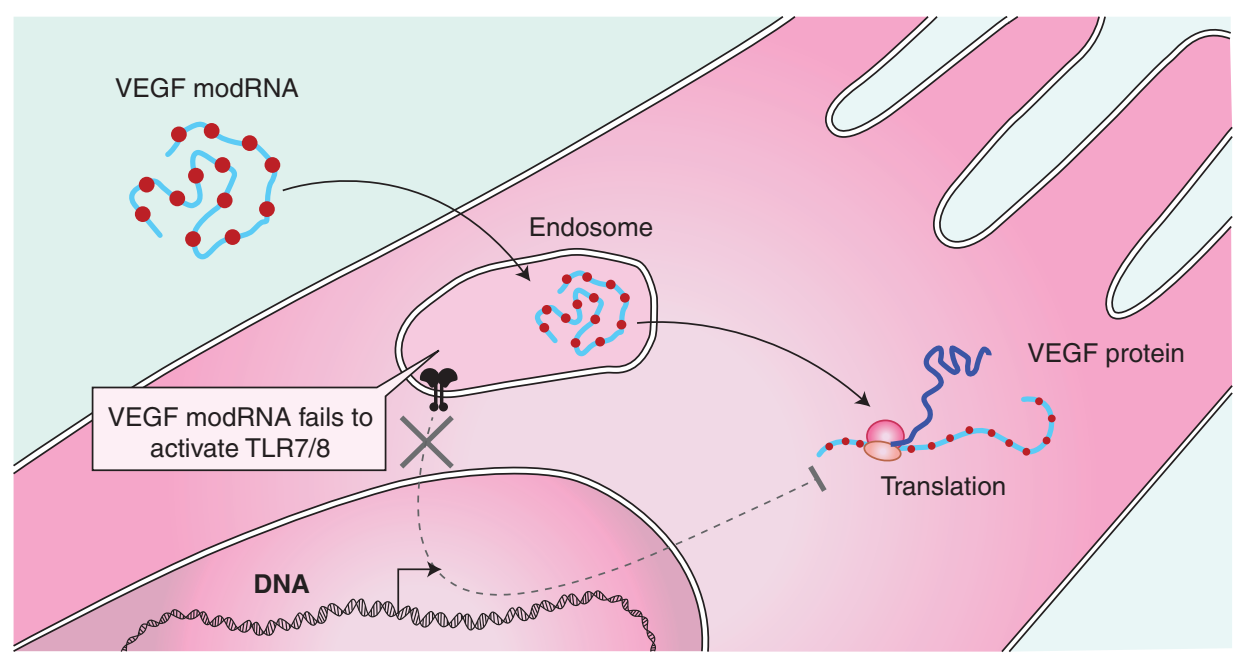

Figure 2. Vascular endothelial growth factor (VEGF) modRNA directs high-efficiency expression of secreted VEGF from cardiomyocytes in vitro and in vivo. VEGF modRNA can be taken up in vitro in diverse cardiomyocytes (mouse, rat, and human) as well as in vivo. The chemically modified modRNA is generated by in vitro transcription by conventional approaches, but there is substitution of chemically modified oligonucleotides that allow the modRNA to escape detection by the Toll-receptor pathways and, hence, to avoid the activation of downstream innate immunity pathways that have traditionally precluded the ability to use unmodified mRNA as an experimental and/or therapeutic agent. Protein synthesis is maintained at a high level within the host cell due to the escape from triggering innate immunity signals, and, thereby, VEGFA protein can be made within the cardiac muscle cells and secreted into the neighboring microenvironment, mimicking the paracrine role of the protein during cardiogenesis. 
K.R. Chien et al.

skeletal (Kormann et al. 2011; Kariko et al. 2012) muscle, including fully differentiated adult rod-shaped cardiac muscle cells as well as fused skeletal muscle myotubes, display high-efficiency expression approaching 95\% (Kormann et al. 2011; Zangi et al. 2013). Using a modified protocol (Table 1), a time- and dose-dependent, high-efficiency expression was also noted by in vivo intracardiac and intramuscular injection, suggesting that modRNA might represent a new approach to direct the expression of any protein of interest. The time course of expression results in a "pulse" of protein expression, and is localized to the region of muscle injection, suggesting that it may be ideal to drive the expression of paracrine signals that are usually transient, intense, and localized (Fig. 3).

\section{PROOF OF CONCEPT: USE OF modRNA TO IDENTIFY PARACRINE FACTORS THAT DRIVE HEART PROGENITOR CELL FATE}

Studies over the past several years have led to the discovery of distinct subsets of heart progenitors that build the mammalian heart (for review, see Martin-Puig et al. 2008; Zhou et al. 2008; Lui et al. 2013b), and a rudimentary cell fate map of the early steps of human cardiogenesis (Fig. 4). In parallel, in vitro assay systems based on human embryonic stem (ES) cell models have allowed the rapid screening of potential paracrine factors that drive their expansion, differentiation, and cell fate specification (Fig. 4). As a proof-of-concept that modified mRNA can be used to identify and drive cell fate decisions of human heart progenitors, VEGF-modified mRNA has been shown to drive multipotent human ES cell-derived heart progenitors toward a vasculogenic cell fate both in vitro (Fig. 4) (Lui et al. 2013a) and in vivo (Zangi et al. 2013). The in vivo administration of VEGFmodified mRNA can lead to pulse of VEGF protein expression, which is dose and time dependent, efficient, transient, intense, and localized to the specific site of injection (Zangi et al. 2013). A single pulse of this paracrine signal, if given at the right time and place after myocardial infarction in vivo, can lead to vascular regeneration and a cell fate switch of the rare epicardial progenitors from contributing to scar formation to becoming part of the neovasculature, resulting in a long-term survival effect (Fig. 4B) (Zangi et al. 2013). Clearly, further work will be required to move the work toward studies in large animals. It will become of interest to determine whether this can be extended to other differentiated cell types in vitro and in vivo, both in the normal state and following injury. In addition, the approach can easily be extended to allow the identification of paracrine

Table 1. Protocol for preparing modified mRNA for in vitro and in vivo transfection

\begin{tabular}{|c|c|}
\hline Model & Protocol \\
\hline In vitro & $\begin{array}{l}\text { In tube } \mathrm{A}, 0.3-3 \mu \mathrm{g} \text { (from stock concentration of } 100 \mathrm{ng} / \mu \mathrm{L} \text { ) of modified mRNA is diluted with } \\
\text { optiMEM in a ratio of } 1: 10 \text {; In tube B, RNAiMAX is diluted with optiMEM in a ratio of 1:10. Both } \\
\text { tubes should be mixed gently and incubated at room temperature separately for } 10 \text { min. After that, } \\
\text { tubes A and B are mixed in the same tube and allowed to incubate at room temperature for an } \\
\text { additional } 20 \text { min. At the end of incubation, the mixture is added to the cells supplemented with } \\
\text { low serum-containing medium }(1-2 \mathrm{~mL} \text { medium for one well of a six-well plate). The cells are } \\
\text { incubated with modified mRNA for } 4-6 \mathrm{~h} \text { and then refreshed with new medium. Note: for } \\
\text { repeated transfections, it is recommended that cells should be pretreated with the B18R protein to } \\
\text { prevent TLR activation before repeated transfections. }\end{array}$ \\
\hline In vivo & $\begin{array}{l}\text { In tube } \mathrm{A}, 100 \mu \mathrm{g} \text { (from stock concentration of } 10-20 \mu \mathrm{g} / \mu \mathrm{L} \text { ) of modified mRNA is diluted } \\
\text { with optiMEM in a ratio of } 1: 1 ; \text { In tube } \mathrm{B}, 40 \mu \mathrm{L} \text { RAiMAX is diluted with } 5 \mu \mathrm{L} \text { optiMEM. } \\
\text { Both tubes should be mixed gently and incubated at room temperature separately for } 10 \mathrm{~min} \text {. } \\
\text { After that, tubes A and B are mixed in the same tube and allowed to incubate at room temperature } \\
\text { for an additional } 20 \text { min. At the end of incubation, the mixture is uploaded into a syringe and } \\
\text { injected intramuscular into the apex area of the heart. No pretreatment of B18R is needed } \\
\text { during in vivo transfection. }\end{array}$ \\
\hline
\end{tabular}



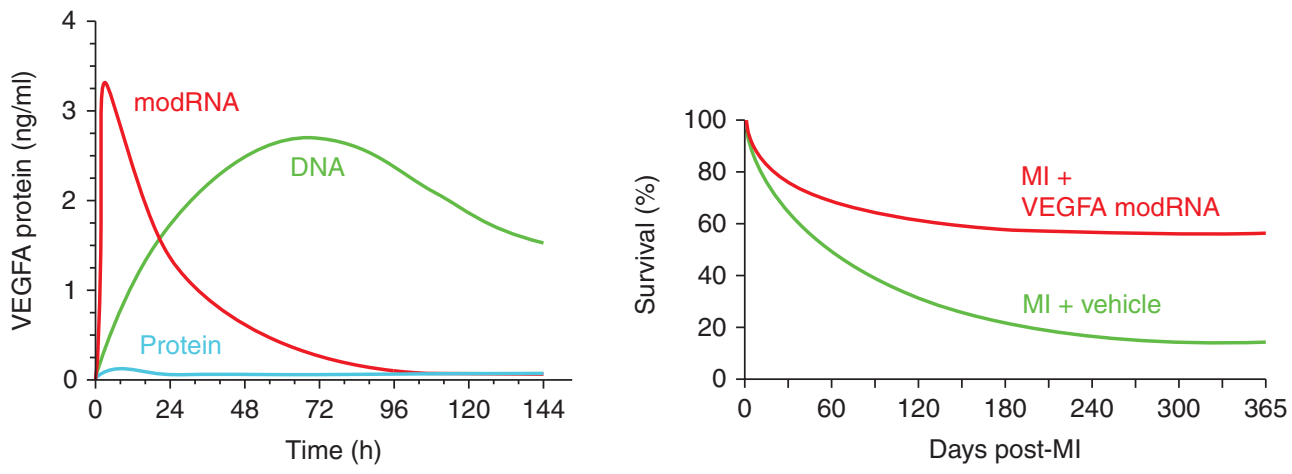

Figure 3. VEGFA modRNA directs a pulse of expression of the paracrine factor in vivo, and a single injection promotes the long-term survival in the intact heart following myocardial infarction (MI) (right). The left panel depicts the relative time course of expression of VEGFA via modRNA strategies versus conventional DNA vectors or exposure to recombinant proteins via intravenous infusion.

factors that drive other heart progenitors toward specific differentiated cell types both in vitro assay systems as well as in in vivo models of injury via the creation of paracrine factor libraries of the modified mRNAs.

\section{ADVANTAGES AND DISADVANTAGES VERSUS CONVENTIONAL GENE TRANSFER APPROACHES}

As noted earlier, there have been a number of technology platforms for manipulating the genetic programs of cardiovascular cell types in vitro and in vivo, each of which has distinct advantages and disadvantages, depending on the biological question and/or therapeutic endpoint/clinical target of interest. Modified mRNA technology is primarily a gain-of-function approach for short-term, localized, intense expression in select tissues that can take up the modified mRNA efficiently and have the translational machinery poised to subsequently make the protein of interest in sufficient quantities to support a biological/therapeutic effect (Kariko et al. 2012; Sanganalmath and Bolli 2013; Zangi et al. 2013). This stands in contrast to viralbased vectors, most recently adeno-associated virus (AAV) (Hendel et al. 2000; Stewart et al. 2006), that allow for longer-term expression, which is optimal for chronic protein replacement therapy (Hinkel et al. 2011), but may be disadvantageous for paracrine signals that will require that the signal immediately on injection and to be shut down after exerting its trigger-like effect on specific target cells of interest. Conventional recombinant protein therapy has been effective via systemic administration (Hendel et al. 2000; Sato et al. 2001; Henry et al. 2003), but localized expression can be problematic because of the shorter half-life of the protein (e.g., VEGF protein half life is on the order of minutes [Carmeliet et al. 1999]), and side-effect profile of systemic administration (e.g., VEGF activation of nitric oxide pathways and subsequent onset of hypotension [Yang et al. 2002]). Modified mRNA does have an intrinsic advantage that it is synthetically derived, can be quickly generated, and does not require viral vectors (Mandal and Rossi 2013), and can be applied to small (Kormann et al. 2011; Kariko et al. 2012; Zangi et al. 2013) and possibly large animal model systems in a facile, cost-effective manner. In addition, the fact that there is no genetic footprint, or danger of integration into the host genome, offers a potential safety advantage.

\section{CHALLENGES AND OPPORTUNITIES FOR MODIFIED mRNA FOR CARDIOVASCULAR THERAPEUTICS}

To unlock the potential of modified mRNA as a tool, technology platform, and potential therapeutic agent for cardiovascular biology and medicine, a number of specific challenges will 
A

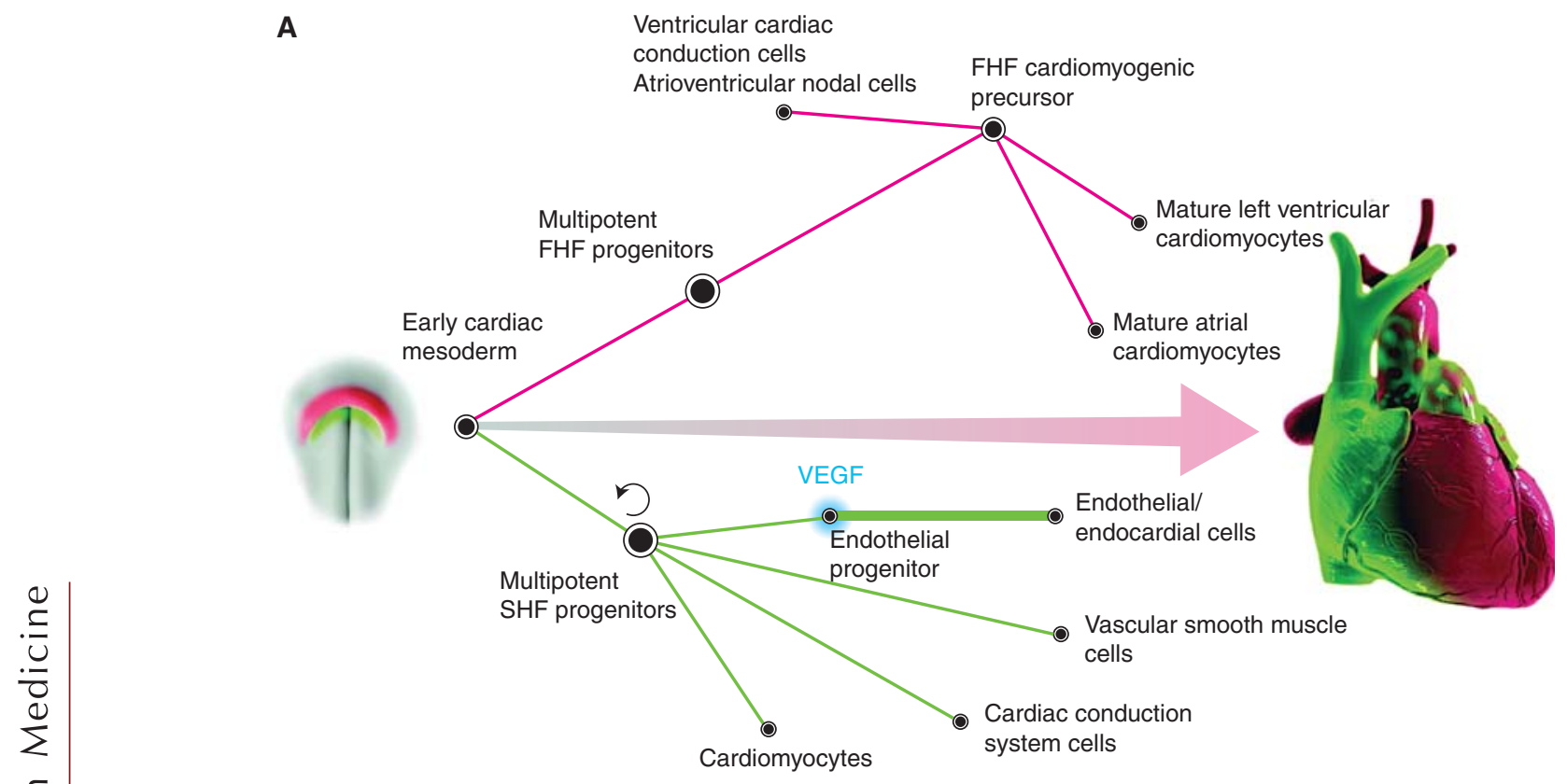

B

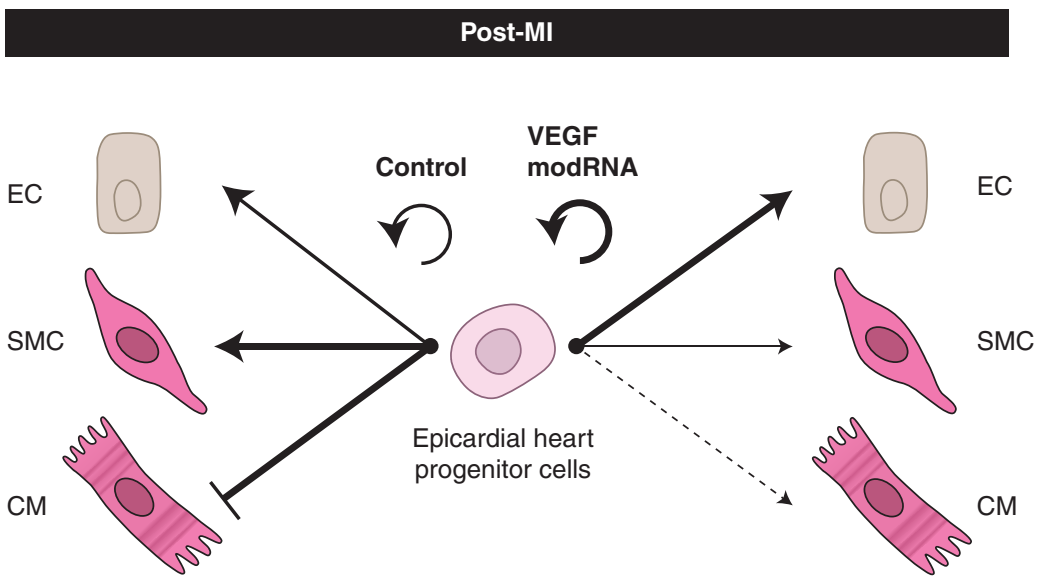

Figure 4. (A) Cardiac mesodermal precursors give rise to two distinct subsets of heart progenitors in the first (FHF) and second heart (SHF) fields, that account for most of the cells within the mammalian heart. The first heart field gives rise mostly to cardiomyocyte lineages and forms the bulk of the left ventricular myocardium. Recent studies have shown that the FHF lineages express the pacemaker channel HCN4 at the earliest stages, and a multipotent FHF exists that is committed to the cardiomyocyte lineage and can give rise to atrial, ventricular, and conduction system cells. The paracrine signals that expand these FHF progenitors are currently unknown. The SHF gives rise to a multipotent SHF progenitor that can give rise to both muscle and nonmuscle cell lineages, including both muscle (cardiac and smooth) as well as endothelial lineages, supporting the view that it plays a major role in heart cell lineage diversification. The multipotent SHF progenitor is expanded by WNT signals, and the the paracrine factor cue of VEGFA can drive a cell fate switch toward vascular endothelial cells, suggesting a new role for the protein in addition to its known effects on the replication of already differentiated endothelial cells and triggering NO signaling pathways. (B) In the adult heart, although FHF and SHF progenitors have largely disappeared, rare epicardial progenitors on the surface of the heart remain in the mature heart and can expand after myocardial infarction to contribute largely to mesenchymal cells and scar formation, with negligible contribution to vascular or cardiac muscle cell lineages. A single administration of VEGFA modRNA in vivo to the adult heart following myocardial injury provides a paracrine factor cue that can expand the epicardial progenitors and drive them away from the formation of mesenchymal cells and subsequent scar formation, and toward a vascular endothelial cell fate, suggesting that VEGFA may be a generalized cue for a vascular cell fate switch in multipotent progenitors. In addition, there is a small but reproducible increase in cardiomyocyte formation from the epicardial progenitors, suggesting that VEGFA may be permissive for an additional paracrine cue, which can drive the formation of differentiated cardiomyocytes from this pool of adult heart progenitors. EC, endothelial cells; SMC, smooth muscle cell; CM, conditioned media. 
have to be addressed. For instance, the chemical modification that have been made thus far have been relatively primitive and will need to be improved to allow negligible signals from innate immunity from being elicited, and opening the door for repeated administration. At the same time, the modifications will need to be biologically compatible, allowing higher translation efficiency. For systemic administration of the modified mRNA, given the experience of siRNA (for review, see Khatri et al. 2012; Vader et al. 2012: Deng et al. 2014), it will be imperative to develop biologically compatible, nontoxic carrier systems to allow delivery to specific organ systems. Because there is no inherent tissue targeting engineered in to the modified mRNA itself (as opposed to ability to use tissue specific promoters in the case of AAV gene therapy vectors [Papadakis et al. 2004; Chen et al. 2013b; Zacchigna et al. 2014]), approaches to destabilize the modified mRNA in nontarget tissues could become of interest.

For delivery to the heart, further optimization and/or development of novel percutaneous catheter-based systems, similar to previously used (Hedman et al. 2003), for the higher efficiency and safe delivery of modified mRNA directly in to the intact heart muscle in vivo will be invaluable. Approaches to prolonging the duration of expression and for repeated systemic delivery, will be required to approach chronic genetic diseases that will require long-term protein replacement therapy. Finally, for clinical use, the scalability, clinical grade material, and cost of goods issues, which are de rigueur for any new biological therapy, will have to be approached in a systematic manner. Over the next several years, if each of these issues can ultimately be addressed, modified mRNA should find a niche in the arsenal of cardiovascular therapeutic platforms, joining the existing ranks of small molecules, recombinant proteins and peptides, antibodies, and the coming age of a new generation of AAV gene therapy vectors.

\section{REFERENCES}

Bolli R, Chugh AR, D'Amario D, Loughran JH, Stoddard MF, Ikram S, Beache GM, Wagner SG, Leri A, Hosoda T, et al. 2011. Cardiac stem cells in patients with ischaemic cardiomyopathy (SCIPIO): Initial results of a randomised phase 1 trial. Lancet 378: 1847-1857.

Braun S. 2004. Naked plasmid DNA for the treatment of muscular dystrophy. Curr Opin Mol Ther 6: 499-505.

Carmeliet P, Ng YS, Nuyens D, Theilmeier G, Brusselmans K, Cornelissen I, Ehler E, Kakkar VV, Stalmans I, Mattot $\mathrm{V}$, et al. 1999. Impaired myocardial angiogenesis and ischemic cardiomyopathy in mice lacking the vascular endothelial growth factor isoforms VEGF164 and VEGF188. Nat Med 5: 495-502.

Chen J, Huang ZP, Seok HY, Ding J, Kataoka M, Zhang Z, Hu X, Wang G, Lin Z, Wang S, et al. 2013a. mir-17-92 cluster is required for and sufficient to induce cardiomyocyte proliferation in postnatal and adult hearts. Circ Res 112: 1557-1566.

Chen SJ, Johnston J, Sandhu A, Bish LT, Hovhannisyan R, Jno-Charles O, Sweeney HL, Wilson JM. 2013b. Enhancing the utility of adeno-associated virus gene transfer through inducible tissue-specific expression. Hum Gene Ther Methods 24: 270-278.

Deng Y, Wang CC, Choy KW, Du Q, Chen J, Wang Q, Li L, Chung TK, Tang T. 2014. Therapeutic potentials of gene silencing by RNA interference: Principles, challenges, and new strategies. Gene 538: 217-227.

Eulalio A, Mano M, Dal Ferro M, Zentilin L, Sinagra G, Zacchigna S, Giacca M. 2012. Functional screening identifies miRNAs inducing cardiac regeneration. Nature 492: 376-381.

Gao J, Liu J, Gao Y, Wang C, Zhao Y, Chen B, Xiao Z, Miao Q, Dai J. 2011. A myocardial patch made of collagen membranes loaded with collagen-binding human vascular endothelial growth factor accelerates healing of the injured rabbit heart. Tissue Eng Part A 17: 2739-2747.

Hagiwara S, Iwasaka H, Shingu C, Matumoto S, Hasegawa A, Nogushi T. 2011. Heat shock protein 47 (HSP47) antisense oligonucleotides reduce cardiac remodeling and improve cardiac function in a rat model of myocardial infarction. Thorac Cardiovasc Surg 59: 386-392.

Hedman M, Hartikainen J, Syvänne M, Stjernvall J, Hedman A, Kivelä A, Vanninen E, Mussalo H, Kauppila E, Simula S, et al. 2003. Safety and feasibility of catheter-based local intracoronary vascular endothelial growth factor gene transfer in the prevention of postangioplasty and in-stent restenosis and in the treatment of chronic myocardial ischemia: Phase II results of the Kuopio Angiogenesis Trial (KAT). Circulation 107: 2677-2683.

Hendel RC, Henry TD, Rocha-Singh K, Isner JM, Kereiakes DJ, Giordano FJ, Simons M, Bonow RO. 2000. Effect of intracoronary recombinant human vascular endothelial growth factor on myocardial perfusion: Evidence for a dose-dependent effect. Circulation 101: 118-121.

Henry TD, Annex BH, McKendall GR, Azrin MA, Lopez JJ, Giordano FJ, Shah PK, Willerson JT, Benza RL, Berman DS, et al. 2003. The VIVA trial: Vascular endothelial growth factor in ischemia for vascular angiogenesis. Circulation 107: 1359-1365.

Hinkel R, Trenkwalder T, Kupatt C. 2011. Gene therapy for ischemic heart disease. Expert Opin Biol Ther 11: 723737.

Hinkel R, Penzkofer D, Zühlke S, Fischer A, Husada W, Xu QF, Baloch E, van Rooij E, Zeiher AM, Kupatt C, et al. 
K.R. Chien et al.

2013. Inhibition of microRNA-92a protects against ischemia/reperfusion injury in a large-animal model. Circulation 128: $1066-1075$.

Kariko K, Ni H, Capodici J, Lamphier M, Weissman D. 2004. mRNA is an endogenous ligand for Toll-like receptor 3 J Biol Chem 279: 12542-12550.

Kariko K, Buckstein M, Ni H, Weissman D. 2005. Suppression of RNA recognition by Toll-like receptors: The impact of nucleoside modification and the evolutionary origin of RNA. Immunity 23, 165-175.

Kariko K, Muramatsu H, Ludwig J, Weissman D. 2011. Generating the optimal mRNA for therapy: HPLC purification eliminates immune activation and improves translation of nucleoside-modified, protein-encoding mRNA. Nucleic Acids Res 39: e142.

Kariko K, Muramatsu H, Keller JM, Weissman D. 2012 Increased erythropoiesis in mice injected with submicrogram quantities of pseudouridine-containing mRNA encoding erythropoietin. Mol Ther 20: 948-953.

Khatri N, Rathi M, Baradia D, Trehan S, Misra A. 2012. In vivo delivery aspects of miRNA, shRNA and siRNA. Crit Rev Ther Drug Carrier Syst 29: 487-527.

Kobara M, Noda K, Kitamura M, Okamoto A, Shiraishi T, Toba H, Matsubara H, Nakata T. 2010. Antibody against interleukin-6 receptor attenuates left ventricular remodelling after myocardial infarction in mice. Cardiovasc Res 87: 424-430.

Kormann MS, Hasenpusch G, Aneja MK, Nica G, Flemmer AW, Herber-Jonat S, Huppmann M, Mays LE, Illenyi M, Schams A, et al. 2011. Expression of therapeutic proteins after delivery of chemically modified mRNA in mice. Nat Biotechnol 29: 154-157.

Lin YD, Luo CY, Hu YN, Yeh ML, Hsueh YC, Chang MY, Tsai DC, Wang JN, Tang MJ, Wei EI, et al. 2012. Instructive nanofiber scaffolds with VEGF create a microenvironment for arteriogenesis and cardiac repair. Sci Transl Med 4: 146ra109.

Losordo DW, Vale PR, Symes JF, Dunnington CH, Esakof DD, Maysky M, Ashare AB, Lathi K, Isner JM. 1998. Gene therapy for myocardial angiogenesis: Initial clinical results with direct myocardial injection of phVEGF $_{165}$ as sole therapy for myocardial ischemia. Circulation 98: 2800-2804.

Lui KO, Zangi L, Silva EA, Bu L, Sahara M, Li RA, Mooney DJ, Chien KR. 2013a. Driving vascular endothelial cell fate of human multipotent $\mathrm{Isll}^{+}$heart progenitors with VEGF modified mRNA. Cell Res 23: 1172-1186.

Lui KO, Stachel MW, Li RA, Bu L. 2013b. Human pluripotent stem cell-derived cardiovascular progenitors for heart regeneration. Drug Discov Today Dis Models 9: e189-e197.

Majmudar MD, Keliher EJ, Heidt T, Leuschner F, Truelove J, Sena BF, Gorbatov R, Iwamoto Y, Dutta P, Wojtkiewicz G, et al. 2013. Monocyte-directed RNAi targeting CCR2 improves infarct healing in atherosclerosis-prone mice. Circulation 127: 2038-2046.

Makkar RR, Smith RR, Cheng K, Malliaras K, Thomson LE, Berman D, Czer LS, Marbán L, Mendizabal A, Johnston PV, et al. 2012. Intracoronary cardiosphere-derived cells for heart regeneration after myocardial infarction (CADUCEUS): A prospective, randomised phase 1 trial. Lancet 379: 895-904.
Malliaras K, Makkar RR, Smith RR, Cheng K, Wu E, Bonow RO, Marbán L, Mendizabal A, Cingolani E, Johnston PV, et al. 2014. Intracoronary cardiosphere-derived cells after myocardial infarction: Evidence of therapeutic regeneration in the final 1-year results of the CADUCEUS trial (CArdiosphere-Derived aUtologous stem CElls to reverse ventricUlar dySfunction). JAm Coll Cardiol 63: 110-122.

Mandal PK, Rossi DJ. 2013. Reprogramming human fibroblasts to pluripotency using modified mRNA. Nat Protoc 8: $568-582$.

Martin-Puig S, Wang Z, Chien KR. 2008. Lives of a heart cell: Tracing the origins of cardiac progenitors. Cell Stem Cell 2: 320-331.

Ni H, Capodici J, Cannon G, Communi D, Boeynaems JM, Karikó K, Weissman D. 2002. Extracellular mRNA induces dendritic cell activation by stimulating tumor necrosis factor- $\alpha$ secretion and signaling through a nucleotide receptor. J Biol Chem 277: 12689-12696.

Papadakis ED, Nicklin SA, Baker AH, White SJ. 2004. Promoters and control elements: Designing expression cassettes for gene therapy. Curr Gene Ther 4: 89-113.

Purdham DM, Rajapurohitam V, Zeidan A, Huang C, Gross GJ, Karmazyn M. 2008. A neutralizing leptin receptor antibody mitigates hypertrophy and hemodynamic dysfunction in the postinfarcted rat heart. Am J Physiol Heart Circ Physiol 295: H441-H446.

Sanganalmath SK, Bolli R. 2013. Cell therapy for heart failure: A comprehensive overview of experimental and clinical studies, current challenges, and future directions. Circ Res 113: 810-834.

Sato K, Wu T, Laham RJ, Johnson RB, Douglas P, Li J, Sellke FW, Bunting S, Simons M, Post MJ. 2001. Efficacy of intracoronary or intravenous $\mathrm{VEGF}_{165}$ in a pig model of chronic myocardial ischemia. J Am Coll Cardiol 37: 616623.

Stewart DJ, Hilton JD, Arnold JM, Gregoire J, Rivard A, Archer SL, Charbonneau F, Cohen E, Curtis M, Buller $\mathrm{CE}$, et al. 2006. Angiogenic gene therapy in patients with nonrevascularizable ischemic heart disease: A phase 2 randomized, controlled trial of AdVEGF ${ }_{121}$ (AdVEGF121) versus maximum medical treatment. Gene Ther 13: 1503-1511.

Stewart DJ, Kutryk MJ, Fitchett D, Freeman M, Camack N, Su Y, Della Siega A, Bilodeau L, Burton JR, Proulx G, et al. 2009. VEGF gene therapy fails to improve perfusion of ischemic myocardium in patients with advanced coronary disease: Results of the NORTHERN trial. Mol Ther 17: 1109-1115.

Taniyama Y, Azuma J, Kunugiza Y, Iekushi K, Rakugi H, Morishita R. 2012. Therapeutic option of plasmid-DNA based gene transfer. Curr Top Med Chem 12: 1630-1637.

Vader P, van der Aa LJ, Storm G, Schiffelers RM, Engbersen JF. 2012. Polymeric carrier systems for siRNA delivery. Curr Top Med Chem 12: 108-119.

van Rooij E, Marshall WS, Olson EN. 2008. Toward microRNA-based therapeutics for heart disease: The sense in antisense. Circ Res 103: 919-928.

Warren L, Manos PD, Ahfeldt T, Loh YH, Li H, Lau F, Ebina W, Mandal PK, Smith ZD, Meissner A, et al. 2010. Highly efficient reprogramming to pluripotency and directed differentiation of human cells with synthetic modified mRNA. Cell Stem Cell 7: 618-630. 
New Technology Platform for Cardiovascular Biology

Weissman D, Ni H, Scales D, Dude A, Capodici J, McGibney K, Abdool A, Isaacs SN, Cannon G, Karikó K. 2000. HIV gag mRNA transfection of dendritic cells (DC) delivers encoded antigen to MHC class I and II molecules, causes DC maturation, and induces a potent human in vitro primary immune response. J Immunol 165: 4710-4717.

Wu J, Zeng F, Huang XP, Chung JC, Konecny F, Weisel RD, Li RK. 2011. Infarct stabilization and cardiac repair with a VEGF-conjugated, injectable hydrogel. Biomaterials 32: $579-586$.

Wu H, Zhu Q, Cai M, Tong X, Liu D, Huang J, Yang G, Jiang Y. 2014. Effect of inhibiting malonyl-CoA decarboxylase on cardiac remodeling after myocardial infarction in rats. Cardiology 127: 236-244.

Yang R, Ogasawara AK, Zioncheck TF, Ren Z, He GW, DeGuzman GG, Pelletier N, Shen BQ, Bunting S, Jin H.
2002. Exaggerated hypotensive effect of vascular endothelial growth factor in spontaneously hypertensive rats. Hypertension 39: 815-820.

Zacchigna S, Zentilin L, Giacca M. 2014. Adeno-associated virus vectors as therapeutic and investigational tools in the cardiovascular system. Circ Res 114: 1827-1846.

Zangi L, Lui KO, von Gise A, Ma Q, Ebina W, Ptaszek LM, Später D, Xu H, Tabebordbar M, Gorbatov R, et al. 2013. Modified mRNA directs the fate of heart progenitor cells and induces vascular regeneration after myocardial infarction. Nat Biotechnol 31: 898-907.

Zhou B, Ma Q, Rajagopal S, Wu SM, Domian I, RiveraFeliciano J, Jiang D, von Gise A, Ikeda S, Chien KR, et al. 2008. Epicardial progenitors contribute to the cardiomyocyte lineage in the developing heart. Nature 454: 109-113. 


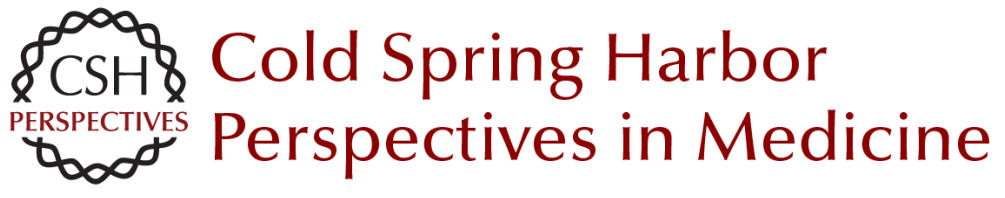

\title{
Synthetic Chemically Modified mRNA (modRNA): Toward a New Technology Platform for Cardiovascular Biology and Medicine
}

\author{
Kenneth R. Chien, Lior Zangi and Kathy O. Lui
}

Cold Spring Harb Perspect Med 2015; doi: 10.1101/cshperspect.a014035 originally published online October 9, 2014

\section{Subject Collection The Biology of Heart Disease}

The Genetic Basis of Aortic Aneurysm

Mark E. Lindsay and Harry C. Dietz

\section{Personalized Genomes and Cardiovascular \\ Disease \\ Kiran Musunuru}

Complex Genetics and the Etiology of Human

Congenital Heart Disease

Bruce D. Gelb and Wendy K. Chung

Genetic Networks Governing Heart Development Ashley J. Waardenberg, Mirana Ramialison, Romaric Bouveret, et al.

Heart Fields and Cardiac Morphogenesis Robert G. Kelly, Margaret E. Buckingham and Antoon F. Moorman

Regenerative Medicine: Transforming the Drug Discovery and Development Paradigm Sotirios K. Karathanasis

Myocardial Tissue Engineering: In Vitro Models Gordana Vunjak Novakovic, Thomas Eschenhagen and Christine Mummery

Pluripotent Stem Cell Models of Human Heart

Disease

Alessandra Moretti, Karl-Ludwig Laugwitz, Tatjana Dorn, et al.
Cardiac Cell Lineages that Form the Heart Sigolène M. Meilhac, Fabienne Lescroart, Cédric Blanpain, et al.

Synthetic Chemically Modified mRNA (modRNA):

Toward a New Technology Platform for

Cardiovascular Biology and Medicine Kenneth R. Chien, Lior Zangi and Kathy O. Lui

Next-Generation Models of Human Cardiogenesis via Genome Editing

Xiaojun Lian, Jiejia Xu, Jinsong Li, et al.

How to Make a Heart Valve: From Embryonic Development to Bioengineering of Living Valve Substitutes

Donal MacGrogan, Guillermo Luxán, Anita

Driessen-Mol, et al.

Insights into the Genetic Structure of Congenital Heart Disease from Human and Murine Studies on Monogenic Disorders

Terence Prendiville, Patrick Y. Jay and William T. $\mathrm{Pu}$

Cardiovascular Drug Discovery: A Perspective from a Research-Based Pharmaceutical Company G. Gromo, J. Mann and J.D. Fitzgerald

Genetics and Disease of Ventricular Muscle Diane Fatkin, Christine E. Seidman and Jonathan G. Seidman

Embryonic Heart Progenitors and Cardiogenesis Thomas Brade, Luna S. Pane, Alessandra Moretti, et al.

For additional articles in this collection, see http://perspectivesinmedicine.cshlp.org/cgi/collection/ 